\title{
Per Jepsen
}

\section{Frihedens skyggespil? - Spinoza og oplysningens dialektik}

\section{Spinoza og oplysningens dialektik}

"Oplysningens dialektik består væsentligt i lysets omslag i mørket" (Horkheimer 1985, 324). Metaforen er næsten så arketypisk, at den selv grænser til det mytologiske, men sådan sammenfatter Horkheimer anno 1960 tesen om oplysningens tilbagefald i mytologi, dens dialektik. Betænker man den periodehistoriske oplysnings egen eksplicitte brug af lysmetaforikken, er formuleringen imidlertid ganske præcis. Oplysningens dialektik betegner da det forhold, at fornuften selv, den sociale og politiske emancipations egen lyskilde, slår om i en ny formørkelse af den sociale verden - dvs. den producerer en ny tvang. Det er i Oplysningens dialektik. Horkheimer og Adornos bestræbelse at bidrage til en erkendelse af de skjulte mekanismer bag denne formørkelse og hermed til en forklaring af det civiliserede barbari, der er oplysningens konsekvens (jf. Horkheimer/Adorno 1995, 25). Meget groft sagt ser de en sådan forklaring $i$ fornuftens reduktion til subjektiv eller instrumentel fornuft, dvs. dens reduktion til middel for opnåelsen af vilkårligt fastsatte mål. Langt fra at være en tilfældig sidegevinst i fornuftens evolution er denne reduktion en konsekvens af dens urhistoriske funktion som naturbeherskelsesinstrument; en funktion der igen forbinder den med myten og de magiske praktikker, den ellers udgrænser som sit modbillede. I den grad det fornuftige reduceres til det nyttige, falder spørgsmålet om det, det er nyttigt for - spørgsmålet om formål - udenfor fornuftens domæne og overlades til det bestående sociale herredømmes interesser. Hvor oplysningen forstået som menneskets herredømme over naturen gennem tænkning oprindeligt havde den menneskelige frigørelse fra tvang som øverste formål, bliver også mennesket hermed offer for rationalitetens selvdestruktive dialektik. Løsrevet fra enhver indholdsmæssig bestemmelse 
slår fornuften som subjektiv fornuft tilbage på menneskene selv og reducerer dem til objekter for instrumentel beherskelse. Det reelle fremskridt i videnskabelig og teknologisk naturbeherskelse, oplysningen også har produceret, ledsages således i stigende grad af en debumanisering af såvel tænkningen som den målrationelt organiserede samfundsvirkelighed (jf. Horkheimer 1947, vi). Hvad der i udgangspunktet var en strategi for den menneskelige frigørelse viser sig i sin yderste historiske konsekvens - den totalt forvaltede verden - som fuldbyrdelse af naturens blinde tvang over menneskene.

Når oplysningen ifølge Horkheimer og Adorno imod sin egen intention ikke formåede at skabe reel menneskelig frihed, skyldes dette ikke mindst, at den $\mathrm{i}$ instrumentaliseringens navn vedvarende har forvekslet denne med den blotte selvopholdelse (jf. Horkheimer/Adorno 1995, 81). Sideløbende med totaliseringen af den subjektive fornuft sker der med andre ord en totalisering af frihedens rent formale aspekt: Selvopholdelsen bliver frihedens øverste grundsætning. Hermed bortelimineres ikke bare enhver kvalitativ og indholdsmæssig bestemmelse af friheden, men forvekslingen af frihed og selvopholdelse fører potentielt til individets fuldstændige identifikation med det samfund, der ret beset bevæger sig imod en total elimination af individet selv (jf. Horkheimer 1987, 328-330). For forfatterne til Oplysningens dialektik bliver Spinozas lære om "bestræbelsen på at bevare sig selv" som "dydens første og eneste grundlag" derfor til "den virkelige læresætning for al vestlig civilisation" (Horkheimer/Adorno 1995, 67). I sin radikale konsekvens er denne maksime ensbetydende med oplysningens omslag i positivisme forstået som "myten om det, som er tilfældet" (ibid, 66). At sætningen om selvopholdelsen som dydens grundlag ikke uden yderligere kvalifikationer giver et retfærdigt billede af Spinozas filosofi skulle sige sig selv. Det er imidlertid heller ikke på nogen måde Horkheimer og Adornos anliggende at bedrive Spinoza-eksegese, men citatet fra Etik tjener til fremhævelse af en overordnet oplysningsdialektisk struktur, der først bliver erfarbar i sin fulde destruktivitet flere århundreder efter Spinoza. Vi skal derfor ikke så meget beskæftige os med, om behandlingen af Spinoza i Oplysningens dialektik er reffardig (hvad den ikke er og heller ikke ubetinget vil vare), men i stedet undersøge den konkrete udviklingslogiske fremgang bag Spinozas egen "reduktion" af frihed til selvbevarelse. Det vil herigennem vise sig, at sammenhængen mellem frihed og selvopholdelse hos Spinoza fremgår på baggrund af en matematisk-rationalistisk ontologi, der indebærer en problematisering af det traditionelle modsætningsforhold mellem frihed og nødvendighed. Fastholder man denne baggrund for Spinozas frihedsbegreb, bekræfter det ikke bare oplysningens dialektik, men peger også ud over den. 


\section{Etikkens negative dimension: Kritikken af viljens fribed}

Spinozas Etik indeholder ikke bare en "etik" i moderne forstand, men også en metafysik, en erkendelsesteori og - med anakronistiske termer - en psykologi hhv. en antropologi. I det hele taget er den mindre optaget af rigide distinktioner mellem de filosofiske discipliner end af den adækvate behandling af sagerne selv. At Etik er fremstillet efter den geometriske metode betyder konkret, at den anvender en såkaldt syntetisk bevismetode, dvs. den går frem fra simple eller elementære propositioner (definitioner og postulater) til mere sammensatte på en sådan måde, at de sidste ved hjælp af deduktive beviser vises at følge logisk af førstnævnte. Den syntetiske opbygning gælder ikke bare for fremgangen i de enkelte dele, men Etik er som helhed syntetisk konstrueret: Teorien om den menneskelige erkendelses former i del II forudsætter i sin begrebslogiske argumentation substansmetafysikken udviklet i første del, etc. Den strengt geometriske fremstilling afbrydes dog indimellem af en række "tillæg" og "anmærkninger", der til sammen giver billedet af en "underjordisk" argumentationsstrategi i Spinozas Etik. Tematisk angår disse afbrydelser mestendels de korrekte filosofiske konsekvenser af matematikken samt de fordomme, der hindrer os $i$ at drage dem: Læren om formålsårsager i naturen samt - ikke mindst - læren om viljens frihed.

Som for de fleste af samtidens filosoffer og videnskabsmænd går vejen til sand menneskelig erkendelse for Spinoza gennem matematikken. Hvor matematikken hos Descartes tjener til konstruktionen af en ny videnskabelig metode, er dens største fortjeneste dog ifølge Spinoza, at den viser os en ny sandhedsnorm: Den nødvendige årsag ${ }^{1}$. Dette gør den i stand til at nedbryde de fordomme, der ellers forhindrer os $i$ at opnå en sand erkendelse af naturen. Og uden en sand erkendelse af naturens principper er også vores selverkendelse - og mulighed for at leve et liv i overensstemmelse med vores egen natur - på gyngende grund. Det er nu Spinozas opfattelse, at alle disse fordomme "afhænger af denne ene, nemlig at menneskene almindeligvis antager, at alle ting i naturen, ligesom de selv, handler for et formåls skyld” (EIapp., Spinoza 1996, 29). I virkeligheden er der dog ikke tale om én, men om hele to fordomme: Når menneskene bilder sig ind, at naturen og sågar "Gud selv" handler efter formål, skyldes det nemlig, at de forstår naturen ud fra en falsk selvforståelse, ifølge hvilken de selv handler efter viljens frie beslutninger og ikke som den nødvendige virkning af bestemte årsager: "Menneskene mener, de er frie, da de jo er sig deres viljesytringer og trang bevidst og ikke i drømme tænker på de årsager, af hvilke de indstilles til at føle trang og ville, fordi de er uvidende om dem" (EIapp., op. cit., 30). Og hvad menneskene end ikke i drømme tænker på at betvivle, deres egen frie vilje, får dem så til at tro, at de mangfoldige ting i na- 
turen, der er nyttige for den menneskelige selvopholdelse, er skabt med denne nytte som formål. Idet de på samme tid indser, at det i de fleste tilfælde ligger udenfor deres egen formåen at skabe tingene på denne måde, slutter de således til, at en anden instans - i. e. Gud - må have skabt tingene med de formål, vi tilskriver dem. Fordommen sniger sig hermed ind i den religiøse praksis, idet menneskene betragter alt i naturen som udtryk for Guds velvilje eller straf over dem: Den bliver til overtro. Og lige så langt en sådan er fra sandheden, lige så langt er den som bekendt $\mathrm{i}$ en rationalistisk optik fra at være uskadelig. Tværtimod fastholder den ifølge Spinoza menneskene i en ufri tilstand, og den er derfor som skabt til at levere ideologisk skyts til dem, der helst ikke ser, at menneskene i det store hele bliver alt for frie. Dette er i Den teologisk-politiske traktat Spinozas argument imod den absolutistiske statsform, der med enkelte kortvarige undtagelser - netop i Spinozas Holland - er dagens ret i 1600-tallets Europa: Overtroen tjener i den tyranniske stat til at holde masserne nede, fordi den maskerer den frygt, der holder dem fast i ufriheden med "religionens besnærende klædning"; hvilket har det klare resultat, at de uafvidende "kæmper for deres trældom som om det var for deres frelse og ikke anser det for en skam [....] at udgyde deres blod for et enkelt menneskes forfængelighed" (TTP, Spinoza 1925, 7). Spinozas naturfilosofisk begrundede kritik af læren om formålsårsager i Etik går således i Den teologisk-politiske traktat sammen med en politisk motiveret kritik af dens religiøse institutionalisering og dennes sociale herredømmefunktion ${ }^{2}$. Bag denne sammenhæng mellem ontologi og politisk kritik ligger det rationalistiske credo, at den sande menneskelige frihed kun kan opstå som følge af sand erkendelse og selvindsigt.

Har matematikken imidlertid én gang sparket stolen væk under formålslæren og banet vej for erkendelsen af den undtagelsesløse nødvendighed, der hersker i naturen, må også fordommen om viljens frihed paradoksalt lade livet. Strategien er her den, at én fordom - finalismen - kritiseres, hvorved også den fordom, der begrundede den første - læren om viljesfriheden - sættes ud af kraft. På Etiks manifeste argumentationsniveau tilbagevises formålslæren gennem en syntetisk følgeudvikling af traditionelle metafysiske begreber som substans og attribut, det endelige og det uendelige, etc. Bag den manifeste argumentation gemmer sig imidlertid den mere grundlæggende, der skinner igennem i de stilistiske afbrydelser af den geometriske fremstillingsgang: Matematikken giver os en ny model for opfattelsen af årsag-virknings-relationerne i naturen og for forholdet mellem det endelige (de endelige modi, ting, ideer) og det uendelige (Gud eller substansen), nemlig at alting sker med nødvendighed og som virkning af en årsag. Den skabte natur er ikke bare i sin eksistens men også i sin indretning underlagt streng nødvendighed, og der er derfor ikke plads til behagelige undtagelser som f.eks. den menneskelige vilje. Tværtimod 
er også viljen en "nødvendig årsag", dvs. "hver enkelt viljesytring [kan] kun eksistere [...], hvis den bestemmes af en anden årsag” (EIp32dem. op. cit., 25). Selvsagt kan Spinoza derfor heller ikke tilslutte sig den opfattelse, at Gud skulle "virke ud fra viljens frihed". Tværtimod har en sådan lære ifølge Spinoza kun den ene funktion at forblænde menneskene og forlænge ufriheden.

\section{Fribed som frigorelse}

Var konklusionen nu, at den menneskelige frihed overhovedet måtte betragtes som en ren og skær fordom, ville der indlysende nok ikke være meget "etik" tilbage i Etik. En lære om det gode liv, der må forudsætte, at der gives et reelt alternativ mellem trældom og frihed, ville da være en meningsløs beskæftigelse. Med den tyske Spinozafortolker Wolfgang Bartuschats ord hører forestillingen om, at det gode liv er en reel menneskelig mulighed imidlertid ikke til de fordomme, der skal nedbrydes i Etik (se Bartuschat 1992, 11). Spinoza vælger derimod en mere "dialektisk" løsning på frihedsproblemet. Anderledes sagt er frihed og nødvendighed hos Spinoza ikke abstrakte modsætninger, men frihed består netop i det kun at eksistere "ud fra sin naturs nødvendighed (min fremhævelse, PJ)" og ligeledes kun bestemmes til handling "ved sig selv" (EIdef7, op.cit., 3). I en natursammenhæng, hvor alting "foregår med en vis evig nødvendighed og med den højeste fuldkommenhed" (EIapp., op. cit., 31), kan frihed ikke, som læren om viljesfriheden foregøgler, indebære en undtagelse fra den nødvendige årsagssammenhæng, men dens mulighedsrum - der, hvor friheden bliver til andet og mere end fordommenes skyggespil - ligger i muligheden for, at tingens bestemthed ikke kommer til den udefra, men fra dens egen natur: At den er selvlovgivende. Virkningshistorisk betragtet peger denne opfattelse frem mod Kants bestemmelse af frihed som autonomi ${ }^{3}$. På samme tid knytter Spinoza med denne karakteristik frihedsbegrebet til den Cartesianske metafysiks begreb om Gud som "causa sui", altså: egen årsag eller årsag til sig selv. Tankevækkende nok er Etiks forste definition netop en definition af dette begreb: "Ved årsag til sig selv, forstår jeg det, hvis essens indbefatter eksistens, eller det, hvis natur kun kan begribes som eksisterende" (EIdef.1, op. cit., 3). Forstår man den tidligere nævnte syntetiske opbygning af Etik som "billede" på et reallogisk forhold, dvs. forstår man som Spinoza den logiske følgerelation som udtryk for en ontologisk (jf. EIIp7, op. cit., 39), kan hele værket betragtes som et forsøg på at skrive "naturens bog" ud fra et absolut selvberoende førsteprincip, nemlig Gud eller substansen, der ved sig selv frembringer mangfoldigheden af love og årsagsrelationer. Efterhånden som siderne vendes, falder også friheden - paradoksalt nok - på plads i nødvendigheden. 
Er frihed defineret som selvlovgivning i betydningen ikke at være underlagt nogen anden nødvendighed end sin egen naturs, er det imidlertid kun Gud, der er fri i absolut forstand. Kun Gud eksisterer og handler udelukkende ud fra sin egen naturs nødvendighed, og kun Gud er derfor "en fri årsag" (EIp17corol2, op. cit., 16). Den præcise argumentation herfor knytter sig til den konkrete udvikling af substansbegrebet i de første femten læresætninger af Del I. Spinoza viser her, at det følger af det metafysiske begreb om substansen som "det, der er i sig selv og begribes ved sig selv" (EIdef3, op. cit., 3), at der kun kan gives én substans og at denne er identisk med Gud forstået som "det absolut uendelige væsen" (EIp14dem., op. cit., 12). I Spinozas metafysiske kosmologi betyder dette, at alt andet er at betragte som substanstilstande eller modi, dvs. som noget, der "er i et andet, ved hvilket det også begribes" (EIdef5, op. cit., 3) ${ }^{4}$. Også mennesket er derfor modus og ikke substans (EIp10, op. cit., 41), og det er henvist til sidstnævnte som yderste årsag for sin eksistens. Yderligere er det som endeligt væsen konstant bestemt af en mangfoldighed af andre endelige årsager (jf. EIp28, op. cit., 22). Skal menneskets frihed være andet og mere end en kimære, må der imidlertid kunne skelnes mellem en situation, hvor mennesket i højere grad eksisterer og virker ud fra sin egen natur og en sådan, hvor det er underlagt en ren fremmedbestemmelse. Det er klart, at der her må være tale om et mere eller mindre, idet kun Gud eller substansen er årsag til sig selv og derfor i absolut forstand fri årsag. Den menneskelige frihed må tænkes som frigorelse fra en situation, hvor det handler mindre i overensstemmelse med sin egen natur, til en situation, hvor det indenfor mulighedens grænser - ud fra sin ontologiske bestemmelse som endelig modifikation af substansen - eksisterer og virker ved sin egen natur. Etikken eller læren om det gode liv er hermed på samme tid henvist til "antropologien", der hos Spinoza er del af en metafysik. Kun ud fra en fuld erkendelse af dets rette plads i naturens orden kan mennesket erkende sin egen natur, og kun ud fra denne kan det drage de praktiske konsekvenser, der adskiller det gode liv fra den blotte selvopholdelse.

\section{Fribed og selvopholdelse. Det positive begreb om fribeden i Spinozas Etik.}

I den grad frihed bestemmes som det ikke at være determineret af andet end sin egen naturs nødvendighed, er spørgsmålet om den menneskelige frihed som nævnt knyttet til "antropologien" eller læren om den menneskelige natur. En sådan fremsættes i Etik dels i tilknytning til erkendelsesteorien i Del II, der behandler spørgsmålet om menneskets væsen qua ånd, dels indenfor rammerne af følelseslæren i tredje del. Spinozas matematisk-rationalistiske synsvinkel indebæ- 
rer dog, at også den menneskelige væren må forstås ud fra de samme nødvendige love, der gælder for naturen overhovedet: "Naturens love og regler, efter hvilke alt sker og forvandles fra en form til en anden, er overalt og altid de samme, og derfor må der også være en og samme fornuftregel for forståelsen af hvilke som helst tings natur, nemlig gennem naturens universelle love og regler" (EIIIpraefatio, op. cit., 78). Læren om viljens frihed forsynder sig netop imod denne altomfattende nødvendighed i naturen, idet den betragter mennesket som delvist undtaget fra de mekaniske love, der gælder for den øvrige natur. Anderledes sagt behandler den de menneskelige følelser og lidenskaber som noget, der forstyrrer og ikke som noget, der folger naturens orden, dvs. den betragter dem som fejl eller mangler ved naturens indretning. For så vidt lidenskaberne således blot er at betragte som mangler ved naturen, er det heller ikke umagen værd at søge efter årsager til dem. Den eneste modgift imod følelsernes tøjlesløse spil er derimod, at de bringes under viljens eller forstandens beherskelse $e^{5}$. Viljens magt til at betvinge følelserne betragtes på sin side som absolut (jf. ibid., 77), hvad der fører til det andet brud på naturens nødvendige årsagssammenhæng.

Heroverfor - og i overensstemmelse med den metafysiske nødvendighedsdoktrin - udvikler Spinoza nu i Etiks tredje og fjerde del en alternativ lære om de menneskelige "handlinger og tilskyndelser", der behandler disse "som hvis der var tale om linjer, flader eller legemer", altså som fænomener, der er underlagt en nødvendig og undtagelsesløs determination (ibid., 78). Det er igen vigtigt at bemærke, at Spinoza ikke hermed er ude på at gøre friheden til en illusion, men at han derimod ønsker at tænke frihed og nødvendighed i sammenhæng. Er man som Spinoza overbevist om, at den matematiske videnskab angår en ontologisk struktur ved tingene selv, altså at tingene selv i deres egenskaber og indbyrdes sammenhæng er underlagt den samme nødvendighed som den, der gælder for forholdet mellem aksiomer og læresætninger i et matematisk bevis, er den eneste mulighed for også at give plads til et begreb om menneskelig frihed, at man opgiver den rigide modsætning mellem frihed og nødvendighed. Frihedens mulighed må tænkes $i$ relation til nødvendigheden, ikke som et absolut brud på den. Den nødvendighed, med hvilken alle ting i naturen "handler", er på sin side udtryk for den guddommelige magt eller virkekraft. Det er af afgørende betydning, at denne "magt" forstås på en ikkeantropomorfistisk måde, dvs. at den ikke forveksles med de magtbegreber, menneskene anvender til at forstå deres egne livsformer og handlinger. Guds magt er ikke en magt til at handle efter forgodtbefindende, men den betegner det forhold, at der ud fra Guds eller substansens natur følger "uendelig mange ting på uendelig mange måder" (EIp16, op. cit., 15). Magt er med andre ord ensbetydende med det at handle ud fra sin egen natur. I betydningen at handle efter vilkårlighed eller forgodtbefindende udtrykker den derimod ikke andet 
end en fejlagtig menneskelig selvforståelse. Den ikke-antropomorfistiske magt eller virkekraft, ved hvilken Gud eller substansen udtrykker sin egen natur, er på sin side centrum i Spinozas metafysiske kosmologi, og - som vi skal se - på samme tid fundamental for den antropologiske lære, ud fra hvilken den menneskelige frihedsform kan indholdsbestemmes.

Idet enkelttingene ifølge Spinoza er at betragte som tilstande ved den guddommelige natur, der følger med nødvendighed af denne, udtrykker de ligeledes "på sikker og bestemt måde" den "magt, ved hvilken Gud er og virker" (EIIIp6dem, op. cit., 83). Som udtryk for den guddommelige virkekraft er hver enkelt ting i sit positive aspekt magt til at eksistere, og den kan derfor kun ødelægges af en anden ting, altså af en ydre årsag. I sig selv er enkelttingen derimod karakteriseret ved en stræben efter "at forblive i sin væren" (ibid., 84). Denne stræben efter selvbevarelse, ved hvilken tingen udtrykker den guddommelige magt, der virker i den, er den ubetingede grundkategori i Spinozas naturontologi. Og eftersom han tænker naturen monistisk, det vil sige som en ubrudt enhed, der udfolder sig omkring substansens allestedsnærværende virkekraft, må også beskrivelsen af den menneskelige væren tage afsæt i denne stræben. Sammenhængen mellem "antropologi" på den ene side og på den anden side metafysik og ontologi lader sig hermed konkretisere: Hvis alting i naturen er kendetegnet ved en stræben efter selvbevarelse, og den menneskelige væren på sin side følger de samme grundlæggende love som den øvrige natur, er den særlige menneskelige væren at forstå som en særlig form for stræben efter selvbevarelse. Denne form kalder Spinoza for drift. Driften er således "selve menneskets essens, for så vidt som den begribes som bestemt til at gore et eller andet ud fra en hvilken som helst given påvirkning” (EIII, aff.def.1, op.cit., 119. Min fremhævelse, PJ). At mennesket på denne måde er bestemt til goren eller til at virke, forklarer dog endnu ikke helt sammenhængen mellem drift og trangen til selvbevarelse. Mennesket kunne vel tænkes at gore og stræbe efter at gøre mange ting, der ikke ligefrem tjente til dets egen selvopholdelse? Med en "moderne" betegnelse: Kan den menneskelige drift ikke ligesåvel tænkes at have en selvdestruktiv som en decideret selvbevarende retning? For at kunne svare på det spørgsmål må man være opmærksom på en anden definition af driften, der findes tidligere i Etiks tredje del. Det hedder her $\mathrm{i}$ anmærkningen til den niende læresætning, at "drift er trang med bevidsthed om trangen" (EIIIp9schol., op.cit, 85. Fremhævelse af Spinoza). Trang er på sin side ikke andet end åndens stræben efter "at forblive $i$ sin varen med en vis, ubestemt varighed" (EIIIp9, op.cit., 84. Fremhævelse af S.). Som det gerne skulle være klart, er denne stræben - og hermed trangen - ikke noget, der udmærker mennesket fremfor andre værender, men den har karakter af en ontologisk grundbestemmelse. Denne grundbestemmelse, der udtrykker det forhold, at 
Gud eller substansen er virkende i naturen, viser sig i antropologien i bestemmelsen drift. Forskellen mellem trang og drift, der altså er en forskel mellem en ontologisk bestemmelse og en "antropologisk", der er afledt af denne, er netop den bevidsthed om trangen, der gør driften til andet og mere end denne. Hvad der adskiller mennesket fra alle andre former for værender - substansen undtaget - er, at det er bevidst om den trang til selvbevarelse, det har tilfælles med disse. Spinoza vælger derfor bevidst ikke at lade trangen indgå i den endelige definition af driften, eftersom der egentlig ikke er nogen forskel mellem "den menneskelige trang og driften" (EIII, aff.def.1, Expl., op.cit., 119. Min fremhævelse, PJ). At driften er trang med bevidsthed om trangen betyder dog ikke, at det enkelte menneske i den konkrete situation altid er sig sin trang bevidst $i$ betydningen at have en sand eller adækvat erkendelse af trangen og dens motiver. Tværtimod driver denne ikke sjældent sit dulgte spil med det enkelte menneske, der ofte på samme tid drages $i$ forskellige og indbyrdes modsatte retninger, så at han til sidst slet ikke ved "hvor han skal vende sig hen". Forskellen må derimod være - lad dette i hvert fald være vores påstand - at den menneskelige trang (driften) qua bevidst er potentielt erkendbar, og at det enkelte menneske således ved at erkende sin egen trangs natur, langsomt selv kan gøre sig til herre over dens retning. Spinoza bedriver her psykoterapi flere århundreder før, sjælen bliver til sjæleøkonomi - et forhold, der uden tvivl har været medvirkende til den veneration, Freud ved flere lejligheder afslørede at nære for Spinoza. På samme tid må de selvdestruktive aspekter af det menneskelige drifts- eller rettere trangsliv i Spinozas optik henføres til en manglende erkendelse af, hvad der i sandhed skader eller gavner selvbevarelsen, dvs. til en manglende erkendelse af betingelserne for en fuld realisation af driften. Og netop her kommer friheden ind i billedet: Hvis frihed som tidligere nævnt er ensbetydende med i så høj grad som muligt kun at være bestemt til at handle gennem sin egen natur, må den menneskelige frihed bestå $i$ den fuldest mulige realisering af driften forstået som en bevidst styring af den naturlige selvopholdelsestrang. For at kunne skelne mellem en fri hhv. en ufri menneskelig eksistensform må vi med andre ord kunne skelne mellem større hhv. mindre realisationsgrader af driften. Selvsagt hænger denne skelnen sammen med overgangen fra den blinde til den bevidste trang, eller med Spinozas egen formulering: Fra en "blind" til en "seende" nødvendighed.

Nu kan den menneskelige drift ifølge Spinoza udfoldes på to forskellige måder, der ligeledes svarer til to forskellige realisationsgrader. I den grad mennesket er adækvat årsag, dvs. i den grad det er årsag til en virkning, der kan "opfattes klart og tydeligt" ved dets væsensbeskaffenhed (EIIIdef1, op.cit., 78) er det ifølge Spinoza aktivt og eksisterer $i$ bojere grad ud fra sin natur, mens det i den grad, det kun er delvis eller inadækvat årsag til en virkning, bestem- 
mes som passivt og kun i mindre grad eksisterer ud fra sin natur. Hvor det er inadækvat årsag til en virkning, handler en anden årsag så at sige bag om ryggen på mennesket, og virkningen er således kun i ringe grad et produkt af den menneskelige handling, omend denne fremtræder som dens direkte årsag. Også her kunne man - selvfølgelig ikke uden en vis anakronisme - trække paralleller til Freuds psykoanalyse: De bevidste motiver, der rører sig i den neurotiske person, er også kun tilsyneladende årsag til dennes handlinger, mens det i virkeligheden er en række fra den bevidste Jeg-sfære bortcensurerede tilskyndelser, der driver deres spil i de konkrete handlingsakter. Hvor mennesket i Spinozas terminologi handler som inadækvat årsag er det med andre - nemlig Freuds - ord endnu ikke "herre i eget hus", men det bevæges hid og did af de årsager, der bestemmer det til handling. Derimod må den frie tilstand, i hvilken mennesket er adækvat årsag til sine virkninger, forstås som udtryk for en stigende transparens i forholdet mellem årsag og virkning, der ligeledes indebærer en større grad af autonomi for det handlende subjekt. At det, der følger af vores natur "kan forstås klart og tydeligt ved denne alene" (EIIIdef2, op.cit., 78) betyder således, at det så vidt muligt kun er bestemt af denne og hermed er at betragte som en uhindret udfoldelse af subjektets egen magt til at eksistere, dets aktivitet. Sådanne aktive tilstande kan ifølge Spinoza kun opstå af det, han kalder "adækvate ideer", mens de passive tilstande, i hvilke mennesket kun er delvis eller inadækvat årsag til sine virkninger, hidrører fra inadækvate, dvs. "stykkevise og forvirrede ideer" (EIIp35, op.cit., 60). Frihedens problem bliver hermed et spørgsmål om at forvandle forvirrede ideer til adækvate. Dette betyder for Spinoza, at de passive lidenskaber, der dækker over, hvad vi normalt forstår ved "følelser" og "lidenskaber" overhovedet, må forvandles til aktive tilstande baseret på fornuft. En sådan forvandling af følelserne kan kun ske, idet vi danner klare og tydelige ideer om dem, altså idet vi erkender deres sande årsager. Hermed mister de gradvis deres magt over vores handlinger. Omvendt er friheden forstået som åndens "magt" over følelserne knyttet til dens grad af erkendelse af dem (jf. EVp20schol., op.cit., 197). Den menneskelige frihed er således kun mulig i form af en frigørelse fra de passive følelsestilstande og en overgang til et liv i overensstemmelse med fornuften, der er menneskets "sande handlekraft eller dyd" (EIVp52dem, op.cit., 164). Denne frigørelse beror - i modsætning til hovedstrømmen i datidens rationalistiske filosofier - ikke på fornuftens absolute magt over følelserne, og heller ikke på antagelsen af en fri vilje, der er unddraget den nødvendige årsag-virkningssammenhæng, der gælder for naturfænomenerne. Ligeledes forudsætter den en rationel betragtning af følelserne, der ikke på forhånd ignorerer eller benægter disses særegne logik. Sand frihed kan kun komme i stand, idet man grundlæggende accepterer denne logik og herudfra 
forsøger at vende den til sin egen - og det vil sige den egne selvopholdelses - fordel. Subjektets kamp for at blive herre i eget hus - en kamp, der, som vi har set, udspiller sig gennem overvindelsen af de passive følelsestilstande og indtagelsen af et fornuftsperspektiv på disse - forudsætter således heller ikke en overskridelse af naturnødvendigheden, men fornuften stræber essentielt set efter det samme som lidenskaberne, nemlig selvbevarelse. Det er frihedens kendetegn, at denne stræben ikke længere foregår blindt og bag om ryggen på subjektet, men seende, gennem fornuftens utilslørede blik.

\section{Epilog: Spinoza og oplysningens dialektik II.}

Det har ifølge Horkheimer og Adorno fra begyndelsen været oplysningens mål "at tage frygten bort fra menneskene og at indsætte dem som herrer" (Horkheimer/Adorno 1995, 35). "Oplysning" forstås her i sin "videste betydning" som "fremadskridende tænkning" (ibid.) og altså ikke som snæver periodehistorisk kategori. Også Spinozas Etik repræsenterer således for Horkheimer og Adorno en station på den Vesteuropæiske oplysnings vej. Ligeledes er Spinozas lære om selvbevarelsen som dydens grundlag - som nævnt i indledningen - ifølge forfatterne til Oplysningens dialektik et mønstereksempel på oplysningens skæbnesvangre forveksling af frihed med selvopholdelse. Om frygt skriver Spinoza i definitionerne af følelserne i Etiks tredje del, at den er "en ustadig sorg opstået af ideen om en fremtidig eller fortidig ting, om hvis udfald vi til en vis grad nærer tvivl". Sorg er på sin side "menneskets overgang fra en større til en mindre fuldkommenhed", dvs. "en akt, ved hvilken menneskets handlekraft formindskes eller hemmes" (EIIIaff.def.3, op. cit., 120). Som de passive følelser i det hele taget er også frygten ifølge Spinoza kendetegn på en ufri menneskelig eksistens, idet friheden jo netop består i så uhæmmet en udfoldelse af handlekraften som muligt. Tilligemed beror den religiøse undertrykkelse i den absolutistiske stat, som vi har set, på det forhold, at masserne gennem overtroen fastholdes $i$ frygten, altså i deres ufrie eksistens. Det er derfor ingen overdrivelse at sige, at Spinozas filosofi (også) handler om overvindelsen af frygt. Ifølge Spinoza kan vi kun komme frygten til livs ved - som passiv følelsestilstand - at omdanne den til en aktiv, hvad der må ske ved en adækvat erkendelse af frygtens egen mekanik. Faktisk gives der i Etik en helt konkret anvisning herpå: ” [...] for at aflægge frygt [må man] gøre selvhævdelsen til genstand for eftertanke; man må nemlig opregne og ofte forestille sig de sædvanlige livsfarer og tillige, hvorledes de ved åndsnærværelse og sjælsstyrke bedst kan undgås og overvindes" (EVp10schol., op. cit., 194). Altså: Vi kan kun overvinde frygten, idet vi erkender 1) under hvilke 
omstændigheder, den almindeligvis indtræffer, 2) hvordan vi kan undgå, at dette sker, eller 2a) hvordan vi - ved fornuft - kan neutralisere følelsens magt, når skaden er sket. Alt sammen i selvopholdelsens hellige navn. Og tydeligvis har selvopholdelsen karakter af menneskets tilpasning til omstændighederne, hvorved den frihed, der resulterer, heller ikke stammer fra en overvindelse af frygtens genstand, men fra subjektets tillærte indifferens overfor den magt, den udøver. Hvad der her skinner igennem er ikke blot det stoiske forbillede for Spinozas etik, men også den overordnede sammenhæng mellem frihed og naturbeherskelse i den nyere tids filosofi: Subjektet larer sig friheden, i det omfang det lærer at beherske såvel den ydre som den indre natur - og det vil også sige i det omfang, det evner at gøre sig selv til genstand for beherskelse. Det er ikke urimeligt i denne sammenhæng at tale om "oplysningens dialektik".

Også for en tænkning, der med Horkheimer og Adorno ønsker at fastholde mulighederne for sand frihed og humanitet (jf. Horkheimer/Adorno 1995, 22) - imod historiens "objektive" gang - må Spinoza imidlertid have interesse som andet og mere end et eksempel på frihedens skyggespil og vildveje: Hvor frihed i store dele af den aktuelle politiske og filosofiske diskussion uden videre gøres til et spørgsmål om valgfrihed (begreberne om konkurrence-, ytrings- og meningsfrihed indbefattet), mens det reelle valg på den anden side skrumper ind til det illusoriske, har Spinozas indsigt i viljesfrihedens "ideologiske" karakter - men af socialfilosofiske, ikke af ontologiske grunde - et vigtigt ord at skulle have sagt. Og skal friheden på sin side aflægge denne ideologiske karakter - hvad der stadigvæk kun kan ske gennem frigorelse, af politisk og pædagogisk art - må det ufrugtbare alternativ mellem voluntaristiske og deterministiske positioner vige pladsen for en besindelse på frihedens dialektiske relation til den nødvendighed, der i udgangspunktet gør den til en ren og skær kimære. Spinozas Etike er her kun overgået af få.

\section{Litteratur}

Bartuschat, Wolfgang: (1992) Spinozas Theorie des Menschen, Hamburg.

Descartes, Rene: ([1637] 1996a) Om metoden, København.

Horkheimer, Max og Adorno, Theodor W.: ([1947] 1996b) Oplysningens dialektik, København.

Horkheimer, Max: (1947) Eclipse of Reason, New York.

Horkheimer, Max: (1985) Notizen, in Gesammelte Schriften, Band 6, Frankfurt am Main.

Horkheimer, Max: (1987) Vernunft und Selbsterbaltung, i: Gesammelte Schriften, Band 5, Frankfurt am Main.

Kant, Immanuel: ([1788] 1990) Kritike derpraktischen Vernunft, Hamburg. 


\section{Frihedens skyggespil? - Spinoza og oplysningens dialektik}

Spinoza, Baruch de: ([1677] 1996) Etik,.overs. S. V. Rasmussen, revideret af C. H. Koch, København.

Spinoza, Baruch de: ([1670] 1925) Tractatus theologico-politicus, red. C. Gebhardt, Heidelberg.

\section{Noter}

1 Forskellen mellem Descartes og Spinoza, der ofte overses i diskussionen af det matematiske metodeideal i 1600-tallets filosofi, viser sig her i en forskellig betoning af analyse og syntese i den geometriske bevismetode. Descartes ønsker at grundlægge en ny filosofisk metode, der kan føre til ubetvivlelig sikker erkendelse, og han må derfor foretrække den analytiske bevismetode, der består i en trinvis opløsning af sammensatte propositioner til mere simple. På denne måde kan al erkendelse brydes ned til simple udsagn, og de simple udsagn anerkendes eller forkastes alt efter deres egen evidens (jf. Descartes 1996, 43-44). For Spinoza giver matematikken derimod en model for den undtagelsesløse nødvendighed i naturen. Hans matematiske ideal er derfor den allerede nævnte syntetiske metode, der fremstiller de simple antagelsers nødvendige produktion af konsekvenser.

${ }^{2}$ Spinoza gør sig derfor i Den teologisk-politiske traktat til fortaler for en adskillelse af stat og kirke, der skal give fornuften frit spillerum i indretningen af staten. Traktaten er således et partsindlæg i striden mellem det opblomstrende handelsborgerskab, repræsenteret af det republikanske parti under ledelse af Jan de Witt, og det gamle adelsvælde, repræsenteret af de såkaldte Oraniere, der udspillede sig i datidens Holland. Spinoza identificerede sig åbenlyst med de Witt og republikanismen.

${ }^{3}$ Jf. Kant, Kritik af den praktiske fornuft, \8, Læresætning IV: "Viljens autonomi er det eneste princip for alle moralske love og de pligter, der sømmer sig for disse [...] Sædelighedens eneste princip består nemlig i lovens uafhængighed fra al materie [...]."

${ }^{4}$ Som det vil være de fleste bekendt, skelner Spinozas overordnet mellem "substans", "attribut" og "modus". Begrebet om "attribut" er imidlertid ikke så meget af ontologisk som af erkendelsesteoretisk karakter, idet det betegner "det, som forstanden erkender udgør substansens essens."

${ }^{5}$ Ifølge følgesætningen til 49. Læresætning i Etiks Del II er vilje og forstand "et og det samme" (se Spinoza 1996, 72). 